\title{
Effect of Kinetin on Physiological and Biochemical Properties of Maize Seedlings under Arsenic Stress
}

\author{
Haijuan Wang, Biyu Dai, Xiaogang Shu, Hongbin Wang, and Ping Ning \\ Faculty of Environmental Science and Engineering, Kunming University of Science and Technology, Kunming 650500, China \\ Correspondence should be addressed to Hongbin Wang; whb1974@126.com
}

Received 5 September 2015; Revised 24 November 2015; Accepted 25 November 2015

Academic Editor: Zhaohui Li

Copyright (C) 2015 Haijuan Wang et al. This is an open access article distributed under the Creative Commons Attribution License, which permits unrestricted use, distribution, and reproduction in any medium, provided the original work is properly cited.

\begin{abstract}
The effects of different levels of kinetin (KT) application on the growth, biomass, contents of chlorophyll (Chl a, Chl b, and carotenoid), arsenic uptake, and activities of antioxidant enzymes in maize seedlings under arsenic (As) stress were investigated by a hydroponic experiment. The results showed that KT supplementation increased the biomass in terms of root length, root number, fresh weight, and seedling length, and $\mathrm{KT}$ treatments also improved the contents of $\mathrm{Chl} \mathrm{a}$, As uptake, and Chl a: b ratio compared to cases with As treatment alone. However, no significant changes were observed in carotenoid content, and a reduction was found in $\mathrm{Chl} b$ content of seedlings. KT also increased the activities of catalase (CAT), peroxidase (POD), and superoxide dismutase (SOD) in the leaves of maize seedlings when $0.1 \mathrm{mg} / \mathrm{L} \mathrm{KT}$ and As were applied, which decreased the content of malondialdehyde (MDA). These results suggested that KT could alleviate the toxicity of As to maize seedlings by keeping the stability of chlorophyll, enhancing the activities of antioxidant enzymes, and inhibiting the lipid peroxidation. In conclusion, the alleviation effect of KT in maize seedlings exposed to As stress was clearly observed in the present study.
\end{abstract}

\section{Introduction}

Arsenic (As) has been an element of considerable environmental concern, because of its toxicity and carcinogenic properties [1], resulting from natural geologic activities and anthropogenic sources such as mining, semiconductor manufacturing, forest products, landfill leachates, fertilizers, pesticides, and sewage [2]. Exposure to As (V) caused considerable stress in plants, including disorder of cellular function [3], inhibition of growth [4], biochemical and physiological damage [5], and reduction of crop productivity $[3,6,7]$.

In addition, excess As induces oxidative stress in plants by generating reactive oxygen species (ROS), such as superoxide radicals $\left(\mathrm{O}_{2}{ }^{-}\right)$, hydroxyl radical $\left(\mathrm{OH}^{-}\right)$, and hydrogen peroxide $\left(\mathrm{H}_{2} \mathrm{O}_{2}\right)$ [8]. These species react with lipids, proteins, pigments, and nucleic acids and cause lipid peroxidation, membrane damage, and inactivation of enzymes [9-11]. Plants respond to oxidative stress by increasing the activities of antioxidant enzymes, such as superoxide dismutase (SOD), catalase (CAT), and peroxidase (POD) $[4,10,12-14]$.

Cytokinins are a class of phytohormones and can stimulate water uptake, increase cell division, promote organ development, and lead to the regeneration and proliferation of shoots [15]. Among the cytokinins, KT is the first to be discovered and has been widely used in plants for its growthpromoting, antiaging, and promotion of cell division and differentiation [16-18]. Apart from these effects, KT has an ability to confer resistance to plants against various abiotic stresses [19], such as heavy metal toxicity, drought, and inadequate fertilization [11, 20-23].

The main purpose of this study was to evaluate the effects of KT on growth-promotion and regulation of antioxidant defense in maize seedlings under As stress. The effects of different levels of KT application on growth, seedling biomass, chlorophyll contents, antioxidant enzyme activities, and As uptake in maize seedling were systematically determined under As stress. Our results could be used as indicators to improve plant As tolerance and food safety.

\section{Materials and Methods}

2.1. Plant Materials and Experimental Design. Maize seeds were washed thoroughly by running tap water and distilled 
water and then sown in double distilled water for $24 \mathrm{~h}$. After soaking, 20 healthy and uniformly sized seeds were sown in petri plates that were filled with $130 \mathrm{~mL} \mathrm{1/10} \mathrm{Hoagland's} \mathrm{solu-}$ tion and $100 \mathrm{~mL}$ of $0.5 \mathrm{mg} / \mathrm{L}$ As added as $\mathrm{Na}_{2} \mathrm{HAsO}_{4} \cdot 7 \mathrm{H}_{2} \mathrm{O}$ (control) or with $100 \mathrm{~mL}$ different concentrations of KT. The concentrations of As and $\mathrm{KT}$ were based on the results of previous experiments. The treatments included As $(0.5 \mathrm{mg} / \mathrm{L})$ (control), As + KT1 $(0.5 \mathrm{mg} / \mathrm{L}$ As + $0.1 \mathrm{mg} / \mathrm{L} \mathrm{KT}), \mathrm{As}+\mathrm{KT} 2$ (0.5 mg/L As + $0.5 \mathrm{mg} / \mathrm{L} \mathrm{KT)}$, and As + KT3 (0.5 mg/L As + $1.5 \mathrm{mg} / \mathrm{L} \mathrm{KT}$ ) and each treatment was replicated 3 times. After 12-day growth, the fresh tissues were harvested.

2.2. Determination of Growth Parameters. The harvested seedlings were washed several times by running tap and distilled water and then dried by filter paper. The fresh weight was determined by a digital balance and the root and plant lengths were measured in millimeter. The numbers of the lateral roots were also recorded.

2.3. Determination of As Uptake in Plants. The contents of As in stem and leaves were determined as described previously [24]. The fresh seedlings were thoroughly washed by distilled water and digested with $5 \mathrm{~mL}$ of concentrated $\mathrm{HNO}_{3}$ in a $50 \mathrm{~mL}$ digestion glass tube. These tubes were heated at 80 $90^{\circ} \mathrm{C}$ for $30 \mathrm{~min}, 100 \sim 110^{\circ} \mathrm{C}$ for $30 \mathrm{~min}$, and $120 \sim 130^{\circ} \mathrm{C}$ for $1 \mathrm{~h}$. Later, the tubes were cooled and added with $1 \mathrm{~mL}$ of $30 \% \mathrm{H}_{2} \mathrm{O}_{2}$. The tube contents were mixed and heated at $100 \sim 110^{\circ} \mathrm{C}$ for $30 \mathrm{~min}$ and $120 \sim 130^{\circ} \mathrm{C}$ for $1 \mathrm{~h}$. The mixture was filtered and diluted to a total volume of $25 \mathrm{~mL}$. The concentration of As was determined by atomic fluorescence spectrometry (Beijing Rayleigh Instruments Co., AF-610D2). The As content was expressed as $\mu \mathrm{g} / \mathrm{g}$ fresh weight.

2.4. Analysis of Antioxidant Enzyme Activities. For the determination of antioxidant enzyme activities, $1.0 \mathrm{~g}$ fresh leaf was homogenized in $10 \mathrm{~mL}$ of $50 \mathrm{mmol}$ phosphate buffer $(\mathrm{pH}=$ 7.0) under cool condition in prechilled mortar and pestle. The homogenate was centrifuged at $20,000 \times \mathrm{g}$ for $15 \mathrm{~min}$ at $4^{\circ} \mathrm{C}$, and then the supernatant was stored under cool condition for analysis of SOD, CAT, and POD.

SOD activity was assayed by monitoring the inhibition of photochemical reduction of nitrotetrazolium blue chloride (NBT), according to the method as described by Gao [25]. The reaction solution consisted of $1.5 \mathrm{~mL}$ phosphate buffer ( $\mathrm{pH}=7.0$ ), $0.3 \mathrm{~mL}$ DL-methionine (Met), $0.3 \mathrm{~mL} \mathrm{NBT}, 0.3 \mathrm{~mL}$ riboflavin, $0.3 \mathrm{~mL}$ EDTA- $\mathrm{Na}_{2}, 0.5 \mathrm{~mL}$ distilled water, and $0.1 \mathrm{~mL}$ raw enzyme. The reaction mixture, which was not exposed to light, did not develop color and served as the control. A control reaction was performed without raw enzyme which was replaced by an equal volume of distilled water. The assay was carried out at $25 \sim 35^{\circ} \mathrm{C}$ and the reaction was measured spectrophotometrically at $560 \mathrm{~nm}$. One unit of enzyme activity was defined as the quantity of enzyme that reduced the A560 of control by $50 \%$.

CAT activity was determined according to Gao [25], and the decomposition of $\mathrm{H}_{2} \mathrm{O}_{2}$ was evaluated by measuring the decrease in absorbance at $240 \mathrm{~nm}$ after $3 \mathrm{~min}$. The reaction mixture contained $1.0 \mathrm{~mL}$ Tris- $\mathrm{HCl}$ buffer $(\mathrm{pH}=7.0), 1.7 \mathrm{~mL}$ distilled water, $0.1 \mathrm{~mL}$ enzyme extract, and $0.2 \mathrm{~mL} 100 \mathrm{mmol}$ $\mathrm{H}_{2} \mathrm{O}_{2}$.

POD activity was determined according to Gao [25]. The assay mixture included $1.0 \mathrm{~mL} \mathrm{KH}_{2} \mathrm{PO}_{4}(20 \mathrm{mmol} / \mathrm{L}), 3 \mathrm{~mL}$ of reaction solution containing $50 \mathrm{~mL}$ of $100 \mathrm{mmol}$ phosphate buffer $(\mathrm{pH}=6.0), 28 \mu \mathrm{L}$ guaiacol, and $19 \mu \mathrm{L} 30 \%$ hydrogen peroxide for $3 \mathrm{~min}$ (the time interval was $30 \mathrm{~s}$ ) and $1.0 \mathrm{~mL}$ raw enzyme. The change in absorbance at $460 \mathrm{~nm}$ was recorded for calculating POD activity.

2.5. Measurement of Malondialdehyde (MDA). The level of lipid peroxidation in fresh tissue was measured in terms of malondialdehyde (MDA) content by the thiobarbituric acid (TBA) reaction method according to Gao [25]. $0.5 \mathrm{~g}$ fresh tissues were homogenized in $5 \mathrm{~mL} \mathrm{5 \%}$ trichloroacetic acid (TCA) solution under cool condition and centrifuged at $3,000 \times \mathrm{g}$ for $15 \mathrm{~min}$ at $4^{\circ} \mathrm{C}$, and then the clear supernatant was added to $5 \mathrm{~mL}$ TBA. The mixture was heated in boiling water for $10 \mathrm{~min}$ and then cooled in an ice-bath and centrifuged at $3,000 \times \mathrm{g}$ for $15 \mathrm{~min}$. The absorbance of the supernatant was recorded at 532,600, and $450 \mathrm{~nm}$ for calculating the content of MDA.

2.6. Determination of Chlorophyll Contents. The contents of leaf chlorophyll were determined according to Gao [25]. $0.2 \mathrm{~g}$ fresh leaves were homogenized in $2 \sim 3 \mathrm{~mL} 95 \%$ ethanol with some $\mathrm{CaCO}_{3}$ and $\mathrm{SiO}_{2}$. After centrifugation at $4,000 \times \mathrm{g}$ for $10 \mathrm{~min}$, the absorption of the extracts at $470 \mathrm{~nm}$ (carotenoid), $645 \mathrm{~nm}$ (chlorophyll b), and $662 \mathrm{~nm}$ (chlorophyll a) was recorded for the calculation of the pigment contents.

2.7. Data Analysis. Linear regression was analyzed using SPSS 20 statistical package. One-way ANOVA test was performed followed by Tukey's HSD multiple comparison tests to determine significant differences at significance level $P<$ 0.05 or $P<0.01$ with statistical software SAS 9.2. The figures were drawn by Origin 8.0.

\section{Results}

3.1. Plant Growth. The growth parameters in terms of fresh weight, shoot length, root length, and root number showed different responses when maize seedlings were exposed to As alone and combined treatment of As and KT. The fresh weight (Figure 1(a)) and root length (Figure 1(c)) were significantly increased when $0.1 \mathrm{mg} / \mathrm{L} \mathrm{KT}$ was added, compared to the control (As treatment alone). However, no significant difference was found in seedling length and root numbers between $0.1 \mathrm{mg} / \mathrm{L} \mathrm{KT}$ treatment and control.

A significant increase (12\%) in seedling length (Figure 1(b)) was also observed when treated with As $+0.5 \mathrm{mg} / \mathrm{L} \mathrm{KT}$. Besides, the application of $1.5 \mathrm{mg} / \mathrm{L} \mathrm{KT}$ significantly increased the root numbers (Figure $1(\mathrm{~d})$ ) by $28 \%$ as compared with those at As treatment alone. Moreover, the ameliorative effects were more pronounced on root number than on other growth parameters when exposed to As $+1.5 \mathrm{mg} / \mathrm{L} \mathrm{KT}$ treatments. Furthermore, the alleviative 


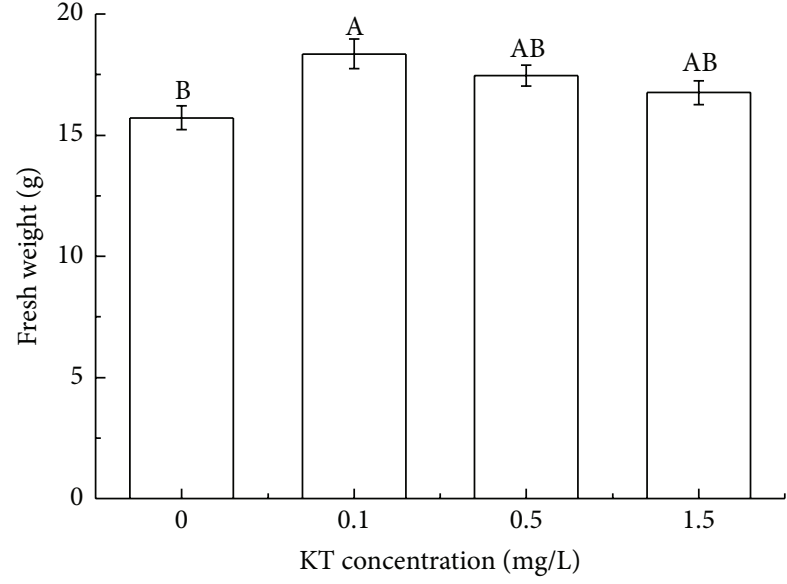

(a)

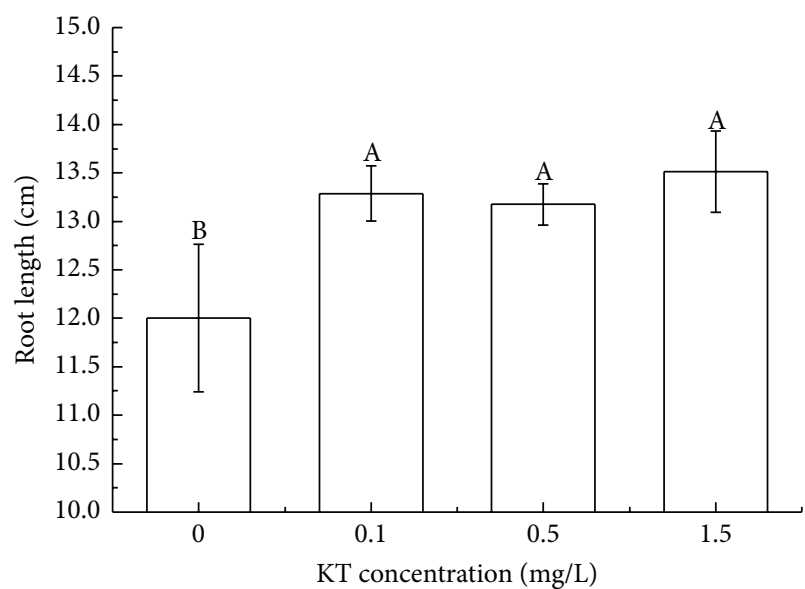

(c)

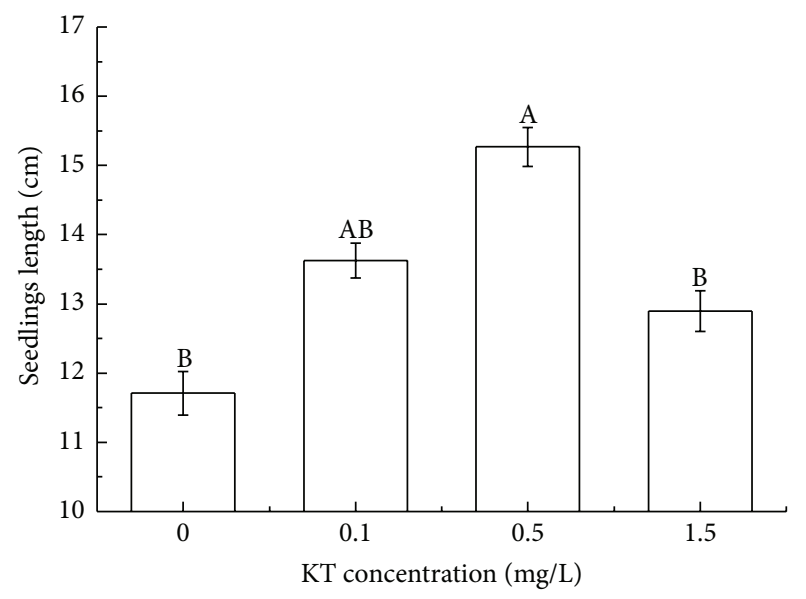

(b)

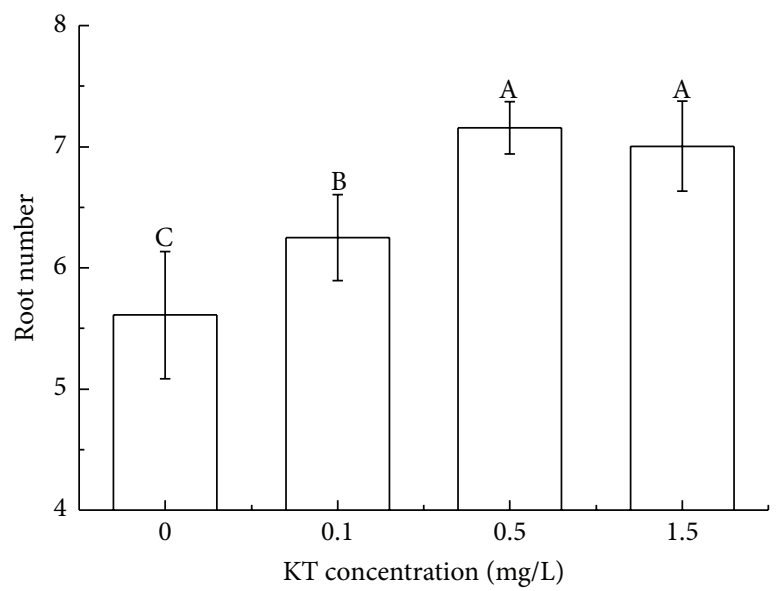

(d)

FiguRE 1: Effects of different concentrations of KT on the growth parameters of maize seedlings under $0.5 \mathrm{mg} / \mathrm{L}$ arsenic stress. Values with different letters indicate a significant difference $(P<0.05)$.

effects of KT on growth parameters of maize seedlings were related to its concentrations.

3.2. Arsenic Uptake. Arsenic contents had no significant difference at $0.1 \mathrm{mg} / \mathrm{L}$ and $0.5 \mathrm{mg} / \mathrm{L} \mathrm{KT}$ treatment compared to the control. However, a significant increase of As in maize seedlings was observed when $1.5 \mathrm{mg} / \mathrm{L} \mathrm{KT}$ was added, indicating high concentration of KT could generate adverse effects on maize seedlings (Figure 2).

\subsection{Activities of Antioxidant Enzyme and MDA Contents}

3.3.1. Activities of SOD. The activity of SOD was significantly increased by $78 \%$ with the addition of $0.1 \mathrm{mg} / \mathrm{L} \mathrm{KT}$ under $0.5 \mathrm{mg} / \mathrm{L}$ As stress compared to the control (Figure 3(a)). However, no significant change was found in SOD activity of maize seedlings with 0.5 or $1.5 \mathrm{mg} / \mathrm{L} \mathrm{KT}$ addition, compared to As treatment alone (Figure 3(a)).

3.3.2. Activities of CAT. CAT activity increased with the increasing concentrations of KT except the $0.5 \mathrm{mg} / \mathrm{L} \mathrm{KT}$ treatment. Furthermore, the CAT activity at $1.5 \mathrm{mg} / \mathrm{L} \mathrm{KT}$ was significantly higher than that at $0.1 \mathrm{mg} / \mathrm{L} \mathrm{KT} \mathrm{(Figure} \mathrm{3(b)).}$

3.3.3. Activities of POD. A significant increase (60\%) of POD activity in maize seedling was noticed when exposed to $1.5 \mathrm{mg} / \mathrm{L} \mathrm{KT}$ under As stress, compared to the control. However, no significant difference was observed among $0,0.1$, and $0.5 \mathrm{mg} / \mathrm{L} \mathrm{KT}$ treatments (Figure 3(c)).

3.3.4. MDA Contents. Application of $\mathrm{KT}$ at three concentrations $(0.1-1.5 \mathrm{mg} / \mathrm{L})$ could significantly reduce the MDA content of maize seedlings compared to the control. However, no significant difference was observed among the three treatments (Figure 3(d)).

3.4. Content of Photosynthetic Pigments. The content of Chl a (Figure 4(b)) and the ratio of Chl a:b (Figure 4(d)) were significantly increased with the $0.5 \mathrm{mg} / \mathrm{L} \mathrm{KT}$ addition. However, Chl b content (Figure 4(a)) showed a decline trend with an increasing level of KT under As stress. Moreover, 


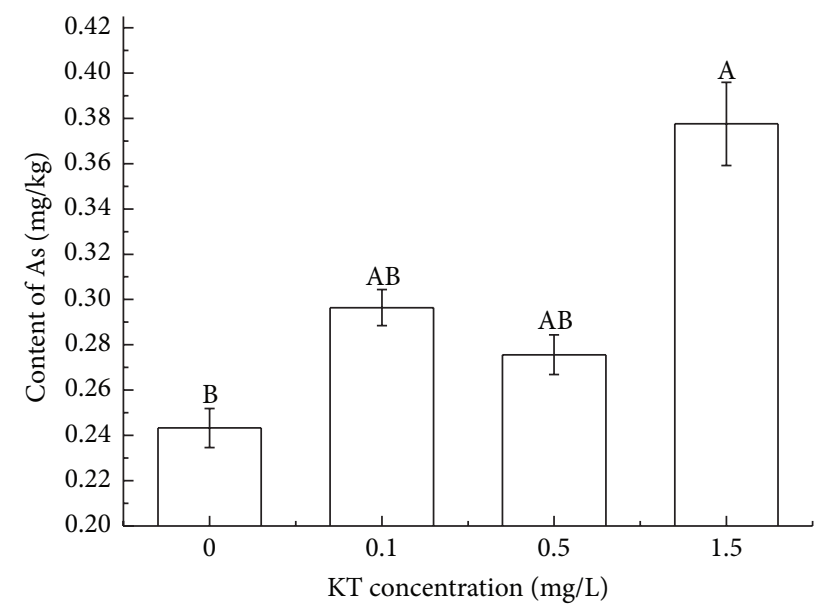

FIGURE 2: Effects of different concentrations of $\mathrm{KT}$ on arsenic uptake in maize seedlings under $0.5 \mathrm{mg} / \mathrm{L}$ arsenic stress. Values with different letters indicate a significant difference.

the content of carotenoid (Figure 4(c)) showed no variation with KT addition (Figure 4).

\section{Discussion}

4.1. Effect of KT on Maize Growth Parameters. It is well documented that heavy metals cause several toxic effects on plants, such as inhibition of seedling growth [26], seed germination [23], reduction of shoot length [27], and root length [28]. Therefore, seed germination, root length, root biomass, shoot length, and seedling growth are generally used to describe metal resistance in plants. Several studies have shown that As can inhibit plant growth [29]. In the present study, we mainly investigated the root number, root length, seedling length, and fresh weight of maize exposed to KT and As treatments. Our results showed that the application of KT alleviated the As-induced inhibition of seedling growth by improving the growth parameters in terms of root length, root number, and fresh weight (Figure 1). It has been reported that KT mitigates the adverse effects of salt stress on plant growth [20]. Similarly, KT addition ameliorates the deleterious effects of Mn pollution [11]. After all, our results showed the ability of KT to counter the toxic effects of As on maize seedling growth. However, the inhibition of seedlings when exposed to As and $1.5 \mathrm{mg} / \mathrm{L} \mathrm{KT}$ may be related to the accelerative accumulation of As in the tested plant.

4.2. Effect of KT on Plant As Uptake. Under our experimental conditions, the contents of As in maize increased with increasing concentrations of KT. It may be attributed to the enhanced root growth and root number, which in turn led to an increasing uptake of As from nutrient media. However, there was no significant difference in plant As uptake between $0.1 \mathrm{mg} / \mathrm{L}$ or $0.5 \mathrm{mg} / \mathrm{L} \mathrm{KT}$ treatment and the control $(0 \mathrm{mg} / \mathrm{L}$ KT) under As stress (Figure 2), suggesting that a suitable concentration of $\mathrm{KT}$ is required to increase plant As uptake.
4.3. Effect of KT on Activities of Antioxidant Enzymes. To cope with the damage caused by oxidative stress, a defensive system in plant is established to decrease the reactive oxygen species, such as the increasing activities of antioxidative enzymes.

SOD is responsible for converting $\mathrm{O}_{2}{ }^{-}$into $\mathrm{H}_{2} \mathrm{O}_{2}$ and $\mathrm{O}_{2}$ [11]. In the present study, the supplement of $0.1 \mathrm{mg} / \mathrm{L} \mathrm{KT}$ increased SOD enzyme activity significantly (Figure 3(a)). This may be related to an increasing level of superoxide radicals $\left(\mathrm{O}_{2}{ }^{-}\right)$induced by As stress, which is consistent with the previous reports [29-31]. However, no significant variation of SOD activity was observed at $0.5 \mathrm{mg} / \mathrm{L}$ or $1.5 \mathrm{mg} / \mathrm{L} \mathrm{KT}$ treatment compared to the control, indicating KT application might have compensated for increased content of superoxide radicals $\left(\mathrm{O}_{2}{ }^{-}\right)$. Prakash et al. [32] have found that $\mathrm{KT}$ acts as a direct radial scavenger and downregulates the lipoxygenase activity to prevent the formation of reactive oxygen species.

CAT is one of the $\mathrm{H}_{2} \mathrm{O}_{2}$-scavenging enzymes in plants and helps in detoxifying harmful metabolic products [33]. An increasing activity of CAT in maize seedlings suggested a possible method in scavenging $\mathrm{H}_{2} \mathrm{O}_{2}$, which in turn decreased the oxidative damage on maize seedling growth (Figure 3(b)).

Excessive $\mathrm{H}_{2} \mathrm{O}_{2}$ may be further detoxified by POD, which is a common response to oxidative stress [12], and an increase of POD activity has been shown in bean plants under As stress [3]. In the present study, $1.5 \mathrm{mg} / \mathrm{L} \mathrm{KT}$ application increased the activity of POD significantly in maize seedlings (Figure 3(c)). It is well documented that POD activity increases in radish after supplying of brassinosteroids under cadmium stress [34]. An enhanced activity of CAT (Figure 3(b)) was concomitant with the increasing POD activity (Figure 3(c)), which might be due to the similar protective mechanism such as decomposing $\mathrm{H}_{2} \mathrm{O}_{2}$ into $\mathrm{H}_{2} \mathrm{O}$ and $\mathrm{O}_{2}$ in maize seedlings under As stress. Moreover, we noticed that an increase of CAT and POD activity and a decrease of SOD activity when exposed to As and $1.5 \mathrm{mg} / \mathrm{L}$ $\mathrm{KT}$, which may result from the accelerative accumulation of As in the tested plant, and the adverse effects of oxidative damage might mainly be induced by excess of $\mathrm{H}_{2} \mathrm{O}_{2}$.

4.4. Effect of KT on MDA. Malondialdehyde (MDA) is a product of peroxidation of unsaturated fatty acids in phospholipids, which may be ascribed to the level of lipid peroxidation [35], and an increase of MDA accumulation as a result of As stress was observed [3]. In the present study, we found that KT application significantly decreased the contents of MDA under As stress (Figure 3(d)), which might be related to a significant increase of SOD and POD activities, and decreased the lipid peroxidation [36]. According to our results, a decrease of MDA in maize seedlings suggested that $\mathrm{KT}$ reduced the As toxicity.

4.5. Effect of KT on Content of Chlorophyll. A high lipid peroxidation coupled with high hydrogen peroxide might have damaged chloroplast and inhibited chlorophyll concentration [14]. Similarly, the photosynthetic pigments are some of the most important internal factors, which are targets of As [7]. 


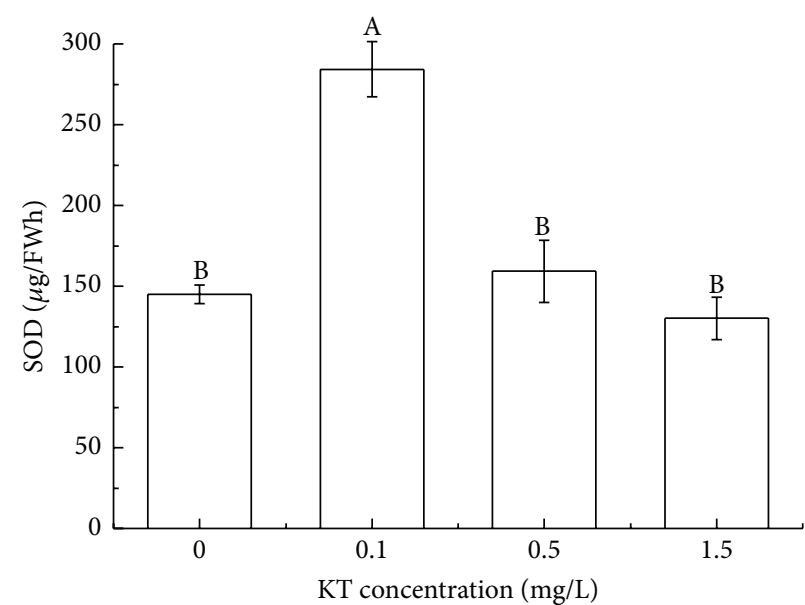

(a)

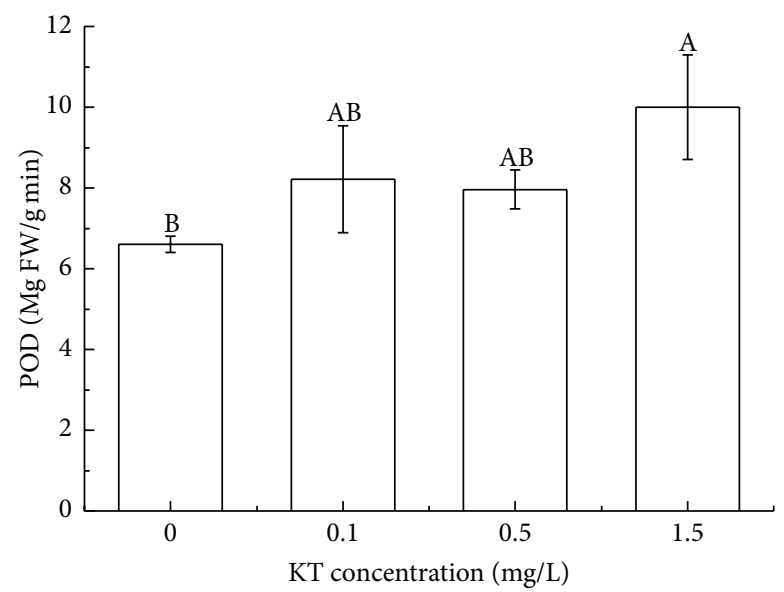

(c)

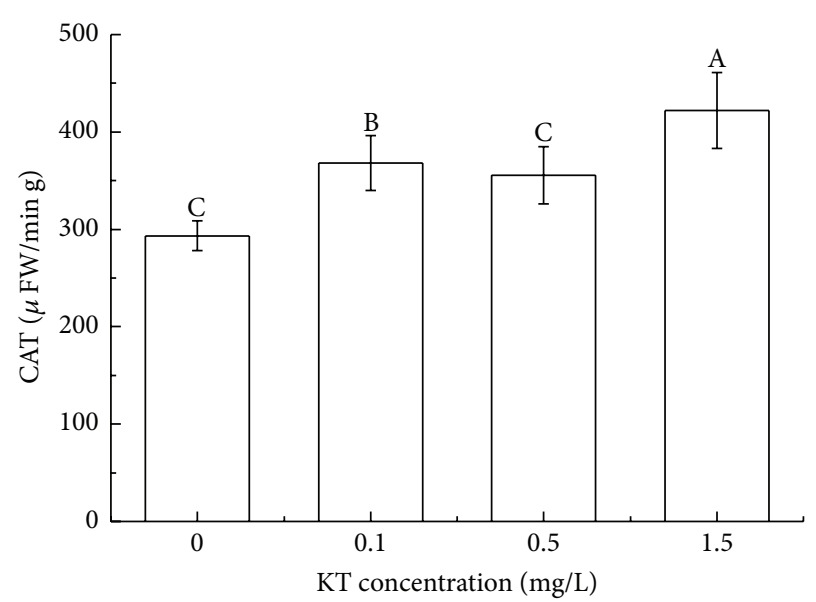

(b)

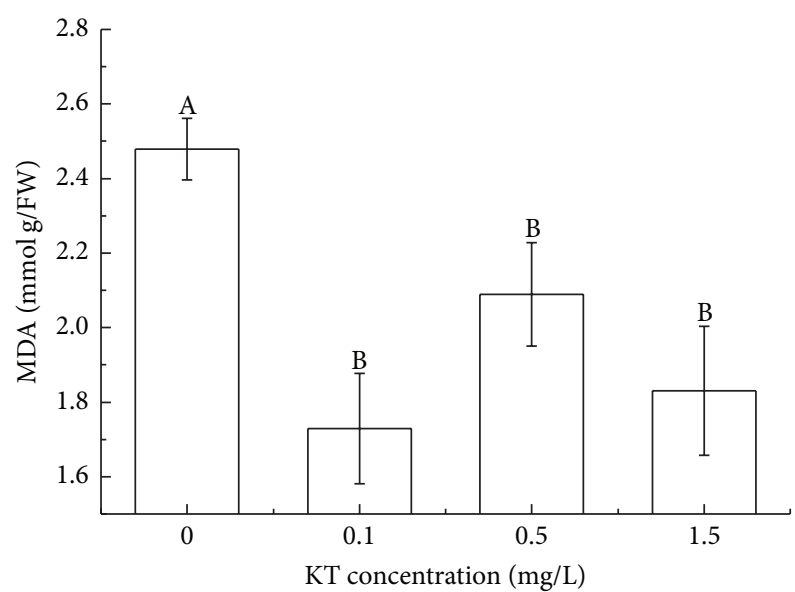

(d)

FIGURE 3: Effects of different concentrations of KT on the activity of antioxidative enzymes and MDA contents in maize seedlings under $0.5 \mathrm{mg} / \mathrm{L}$ arsenic stress. Values with different letters indicate a significant difference $(P<0.05)$.

It has been shown that As damages the chloroplast membrane and disorganizes the membrane structure [3]. The content of Chl a did not significantly change at $0.1 \mathrm{mg} / \mathrm{L}$ KT treatment, but $0.5 \mathrm{mg} / \mathrm{L} \mathrm{KT}$ obviously increased the content of $\mathrm{Chl} \mathrm{a}$ (Figure 4(b)). However, $1.5 \mathrm{mg} / \mathrm{L} \mathrm{KT}$ reversed the increasing trend compared to the control. Therefore, a suitable KT concentration might be responsible for reducing the Asinduced toxicity in maize seedlings. In other words, excess of KT concentration may cause damage to chloroplast and the biosynthesis of photosynthetic pigments.

Ebbs and Uchil [37] reported that the Chl b content drops much more drastically than the $\mathrm{Chl}$ a content as chlorosis progress, which is induced by $\mathrm{Zn}$ and/or Cd. Unlike Chl a, the content of $\mathrm{Chl} b$ showed a decline trend with increasing levels of KT under As stress (Figure 4(a)) compared to the control in the present study. A decrease of $\mathrm{Chl} b$ content indicated that the toxic effects of As on Chl b are greater than those on Chl a.

The contents of carotenoid (Car) showed no significant change with the application of different levels of KT under As tress (Figure 4(c)), indicating Car was less affected compared to chlorophyll. A previous reference shows that carotenoid protects chlorophyll from photooxidative destruction [38].

It is apparent that $\mathrm{Chl} \mathrm{a}: \mathrm{b}$ will increase if $\mathrm{Chl}$ a content increases and/or Chl b content decreases. As shown in our results, an increase of $\mathrm{Chl} \mathrm{a} \mathrm{b}$ indicated that the reduction of $\mathrm{Chl} \mathrm{b}$ was higher than that of $\mathrm{Chl}$ a compared to the control (Figure 4(d)). Increasing Chl a : b is usually associated with the improvement of plant photosynthetic capacity [39].

\section{Conclusion}

KT could mitigate the negative effects of As by enhancing the growth parameters in terms of root length, root number, and fresh weight, improving the activities of antioxidant enzymes (SOD, CAT, and POD), increasing the contents of $\mathrm{Chl}$ a and the ratio of Chl a:b, and decreasing the content of MDA.

\section{Conflict of Interests}

The authors declare that there is no conflict of interests regarding the publication of this paper. 


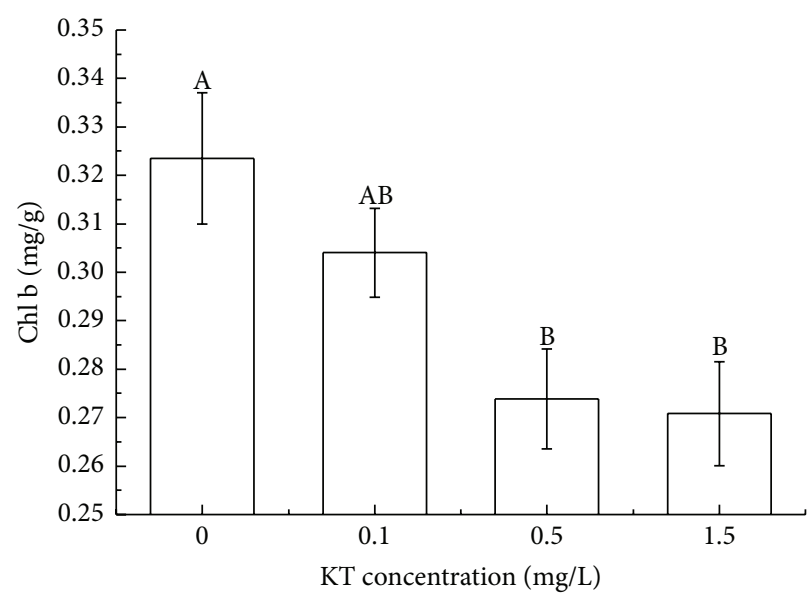

(a)

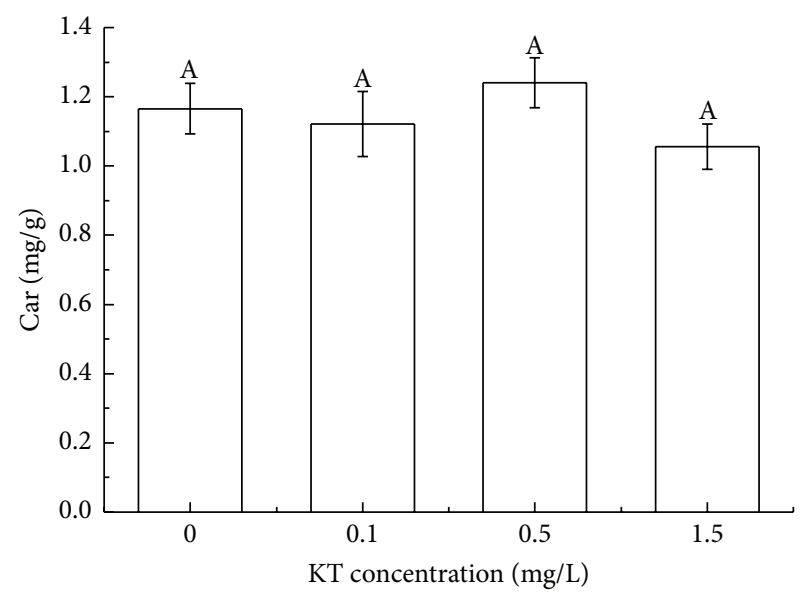

(c)

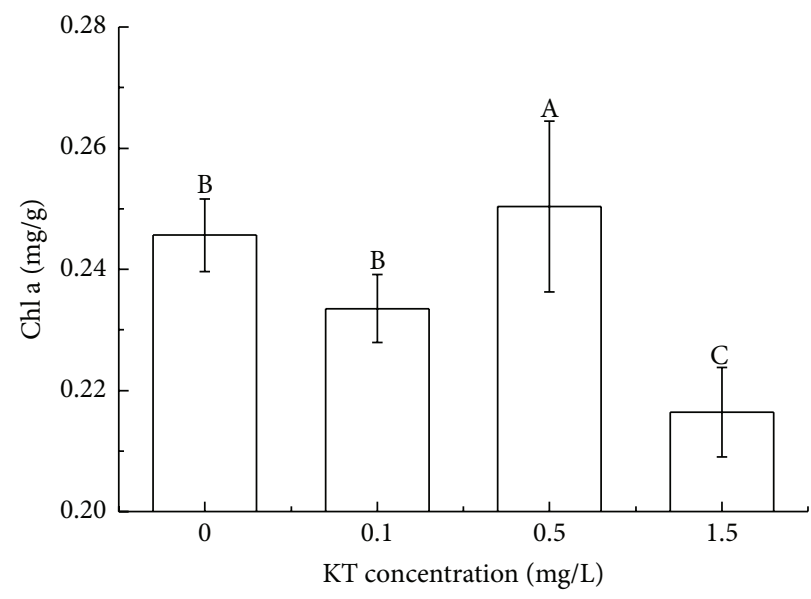

(b)

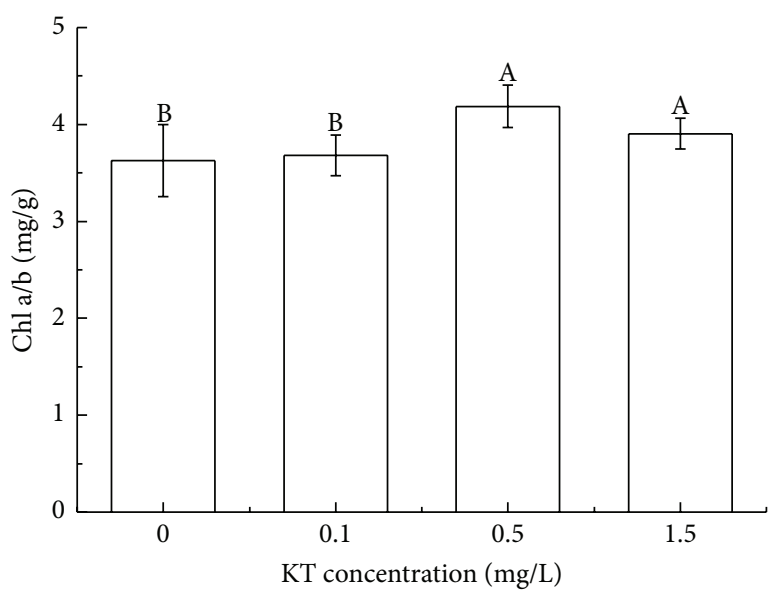

(d)

FIGURE 4: Effects of different concentrations of KT on the contents of photosynthetic pigments in maize seedlings under $0.5 \mathrm{mg} / \mathrm{L}$ arsenic stress. Values with different letters indicate a significant difference $(P<0.05)$.

\section{Acknowledgments}

This work was financially supported by National Natural Science Foundation (no. 31360132), the Department of Environmental Protection in 2010, Heavy Metal Pollution Prevention Projects "Ecological Restoration Technology Demonstration Project of Polluted Farmland in Polymetallic Mining Area, Gejiu, Yunnan," International Cooperation in Science and Technology Project (no. 2014DFA91000), and the Talent Training Fund of Kunming University of Science and Technology (no. KKZ3201222024).

\section{References}

[1] R. D. Tripathi, S. Srivastava, S. Mishra et al., "Arsenic hazards: strategies for tolerance and remediation by plants," Trends in Biotechnology, vol. 25, no. 4, pp. 158-165, 2007.

[2] F. F. Roberto, J. M. Barnes, and D. F. Bruhn, "Evaluation of a GFP reporter gene construct for environmental arsenic detection," Talanta, vol. 58, no. 1, pp. 181-188, 2002.
[3] N. Stoeva, M. Berova, and Z. Zlatev, "Effect of arsenic on some physiological parameters in bean plants," Biologia Plantarum, vol. 49, no. 2, pp. 293-296, 2005.

[4] N. Stoeva and T. Bineva, "Oxidative changes and photosynthesis in oat plants grown in As-contaminated soil," Bulgarian Journal of Plant Physiology, vol. 29, pp. 87-95, 2003.

[5] Y. Li, O. P. Dhankher, L. Carreira et al., "Overexpression of phytochelatin synthase in Arabidopsis leads to enhanced arsenic tolerance and cadmium hypersensitivity," Plant and Cell Physiology, vol. 45, no. 12, pp. 1787-1797, 2004.

[6] V. V. Stepanok, "The effect of arsenic on the yield and elemental composition of agricultural crops," Agrokhimiya, vol. 12, pp. 5763, 1998.

[7] E. Miteva and M. Merakchiyska, "Response of chloroplasts and photosynthetic mechanism of bean plants to excess arsenic in soil," Bulgarian Journal of Agricultural Science, vol. 8, pp. 151156, 2002.

[8] Q. Shi and Z. Zhu, "Effects of exogenous salicylic acid on manganese toxicity, element contents and antioxidative system in cucumber," Environmental and Experimental Botany, vol. 63, no. 1-3, pp. 317-326, 2008. 
[9] A. Molassiotis, T. Sotiropoulos, G. Tanou, G. Diamantidis, and I. Therios, "Boron-induced oxidative damage and antioxidant and nucleolytic responses in shoot tips culture of the apple rootstock EM 9 (Malus domestica Borkh)," Environmental and Experimental Botany, vol. 56, no. 1, pp. 54-62, 2006.

[10] A. Gunes, D. J. Pilbeam, and A. Inal, "Effect of arsenicphosphorus interaction on arsenic-induced oxidative stress in chickpea plants," Plant and Soil, vol. 314, no. 1-2, pp. 211-220, 2009.

[11] S. Gangwar, V. P. Singh, S. M. Prasad, and J. N. Maurya, "Modulation of manganese toxicity in Pisum sativum L. seedlings by kinetin," Scientia Horticulturae, vol. 126, no. 4, pp. 467-474, 2010.

[12] E. Miteva and S. Peycheva, "Arsenic accumulation and effect on peroxidase activity in green bean and tomatoes," Bulgarian Journal of Agricultural Science, vol. 5, pp. 737-740, 1999.

[13] N. Stoeva, M. Berova, and Z. Zlatev, "Physiological response of maize to arsenic contamination," Biologia Plantarum, vol. 47, no. 3, pp. 449-452, 2004.

[14] C.-X. Li, S.-L. Feng, Y. Shao, L.-N. Jiang, X.-Y. Lu, and X.-L. Hou, "Effects of arsenic on seed germination and physiological activities of wheat seedlings," Journal of Environmental Sciences, vol. 19, no. 6, pp. 725-732, 2007.

[15] D. S. Letham and L. M. S. Palni, "The biosynthesis and metabolism of cytokinins," Annual Review of Plant Physiology, vol. 34, no. 1, pp. 163-197, 1983.

[16] R. Vankova, A. Gaudinova, and M. Kaminek, "The effect of interaction of synthetic cytokinin and auxin on production of natural cytokinins by immobilized tobacco cells," in Proceedings of the Symposium on Physiology and Biochemistry of Cytokinins in Plants, pp. 47-51, Federal European Society Plant Physiology, Physiology and Biochemistry of Cytokinins in Plants, 1992.

[17] D. W. S. Mok and M. C. Mok, Cytokinins-Chemistry, Activity and Function, Chemical Rubber Company Press, Boca Raton, Fla, USA, 1994.

[18] Q. X. Wang, F. Zhang, and D. L. Smith, "Application of Ga3 and kinetin to improve corn and soybean seedling emergence at low temperature," Environmental and Experimental Botany, vol. 36, no. 4, pp. 377-383, 1996.

[19] P. Krishna, "Brassinosteroid-mediated stress responses," Journal of Plant Growth Regulation, vol. 22, no. 4, pp. 289-297, 2003.

[20] M. A. A. Gadallah and A. E. El-Enany, "Role of kinetin in alleviation of copper and zinc toxicity in Lupinus termis plants," Plant Growth Regulation, vol. 29, no. 3, pp. 151-160, 1999.

[21] M. M. N. Alla, M. E. Younis, O. A. El-Shihaby, and Z. M. El-Bastawisy, "Kinetin regulation of growth and secondary metabolism in waterlogging and salinity treated Vigna sinensis and Zea mays," Acta Physiologiae Plantarum, vol. 24, no. 1, pp. 19-27, 2002.

[22] N. Chakrabarti and S. Mukherji, "Effect of phytohormone pretreatment on nitrogen metabolism in Vigna radiata under salt stress," Biologia Plantarum, vol. 46, no. 1, pp. 63-66, 2003.

[23] A. M. A. Al-Hakimi, "Modification of cadmium toxicity in pea seedlings by kinetin," Plant, Soil and Environment, vol. 53, no. 3, pp. 129-135, 2007.

[24] L. Ma, H. J. Wang, X. Y. Yang, Y. J. Hu, and H. B. Wang, "The uptake of different arsenic forms in three aquatic plants as affected by $\mathrm{Fe}^{3+}$," Journal of Agro-Environment Science, vol. 32, no. 6, pp. 1111-1121, 2013 (Chinese).

[25] J. F. Gao, Plant Physiology Experimental Guidance, Higher Education Press, Beijing, China, 2006 (Chinese).
[26] Y.-J. An, "Soil ecotoxicity assessment using cadmium sensitive plants," Environmental Pollution, vol. 127, no. 1, pp. 21-26, 2004.

[27] S. Verma and R. S. Dubey, "Lead toxicity induces lipid peroxidation and alters the activities of antioxidant enzymes in growing rice plants," Plant Science, vol. 164, no. 4, pp. 645-655, 2003.

[28] J. Strubińska and A. Hanaka, "Adventitious root system reduces lead uptake and oxidative stress in sunflower seedlings," Biologia Plantarum, vol. 55, no. 4, pp. 771-774, 2011.

[29] J. Hartley-Whitaker, G. Ainsworth, and A. A. Meharg, "Copperand arsenate-induced oxidative stress in Holcus lanatus L. clones with differential sensitivity," Plant, Cell and Environment, vol. 24, no. 7, pp. 713-722, 2001.

[30] P. V. Mylona, A. N. Polidoros, and J. G. Scandalios, "Modulation of antioxidant responses by arsenic in maize," Free Radical Biology and Medicine, vol. 25, no. 4-5, pp. 576-585, 1998.

[31] S. Srivastava, S. Mishra, R. D. Tripathi, S. Dwivedi, P. K. Trivedi, and P. K. Tandon, "Phytochelatins and antioxidant systems respond differentially during arsenite and arsenate stress in Hydrilla verticillata (L.f.) Royle," Environmental Science and Technology, vol. 41, no. 8, pp. 2930-2936, 2007.

[32] T. R. Prakash, P. M. Swamy, P. Suguna, and P. Reddanna, "Characterization and behaviour of 15-lipoxygenase during peanut cotyledonary senescence," Biochemical and Biophysical Research Communications, vol. 172, no. 2, pp. 462-470, 1990.

[33] S. Gangwar, V. P. Singh, S. K. Garg, S. M. Prasad, and J. N. Maurya, "Kinetin supplementation modifies chromium (VI) induced alterations in growth and ammonium assimilation in pea seedlings," Biological Trace Element Research, vol. 144, no. 1-3, pp. 1327-1343, 2011.

[34] A. Anuradha and S. S. R. Rao, "The effect of brassinosteroids on radish (Raphanus sativus L.) seedlings growing under cadmium stress," Plant, Soil and Environment, vol. 53, no. 11, pp. 465-472, 2007.

[35] J. C. Wang, J. Chen, and K. W. Pan, "Effect of exogenous abscisic acid on the level of antioxidants in Atractylodes macrocephala Koidz under lead stress," Environmental Science and Pollution Research, vol. 20, no. 3, pp. 1441-1449, 2013.

[36] M. Shri, S. Kumar, D. Chakrabarty et al., "Effect of arsenic on growth, oxidative stress, and antioxidant system in rice seedlings," Ecotoxicology and Environmental Safety, vol. 72, no. 4, pp. 1102-1110, 2009.

[37] S. Ebbs and S. Uchil, "Cadmium and zinc induced chlorosis in Indian mustard [Brassica juncea (L.) Czern] involves preferential loss of chlorophyll b," Photosynthetica, vol. 46, no. 1, pp. 49$55,2008$.

[38] E. M. Middleton and A. H. Teramura, "The role of flavonol glycosides and carotenoids in protecting soybean from ultravioletB damage," Plant Physiology, vol. 103, no. 3, pp. 741-752, 1993.

[39] L. Feng, M.-J. Gao, R.-Y. Hou et al., "Determination of quality constituents in the young leaves of albino tea cultivars," Food Chemistry, vol. 155, pp. 98-104, 2014. 

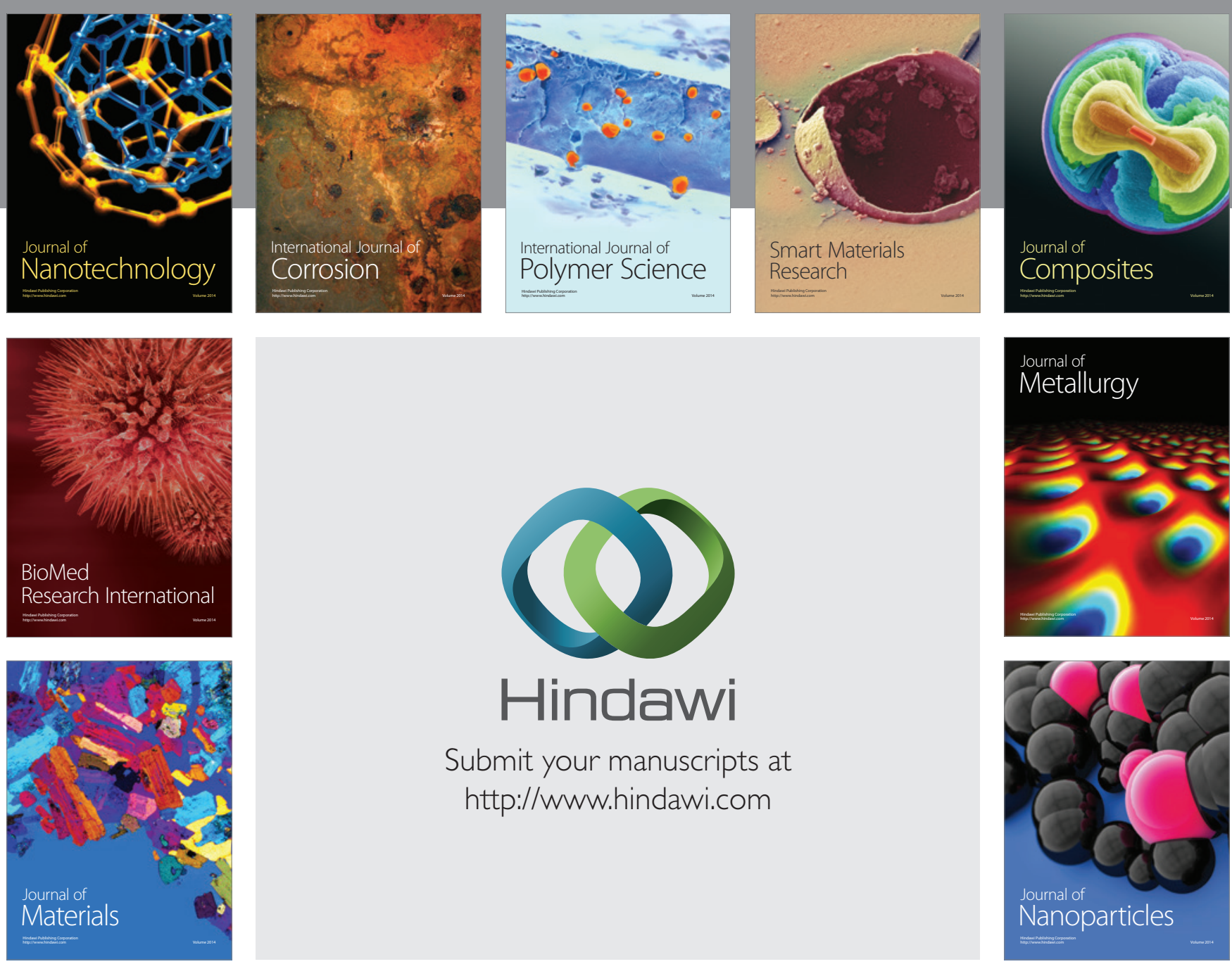

Submit your manuscripts at http://www.hindawi.com
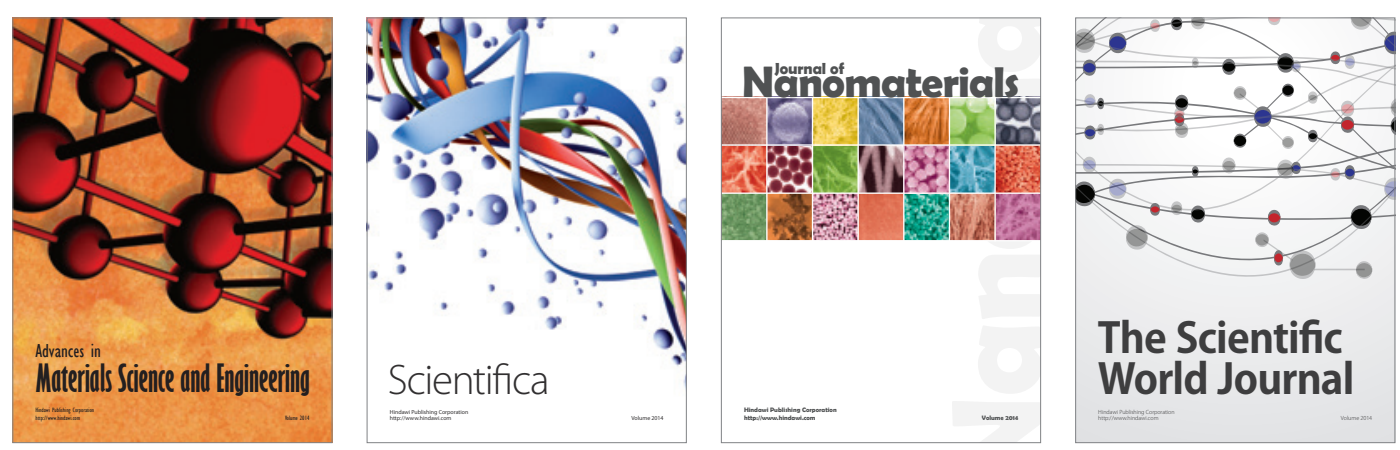

\section{The Scientific World Journal}
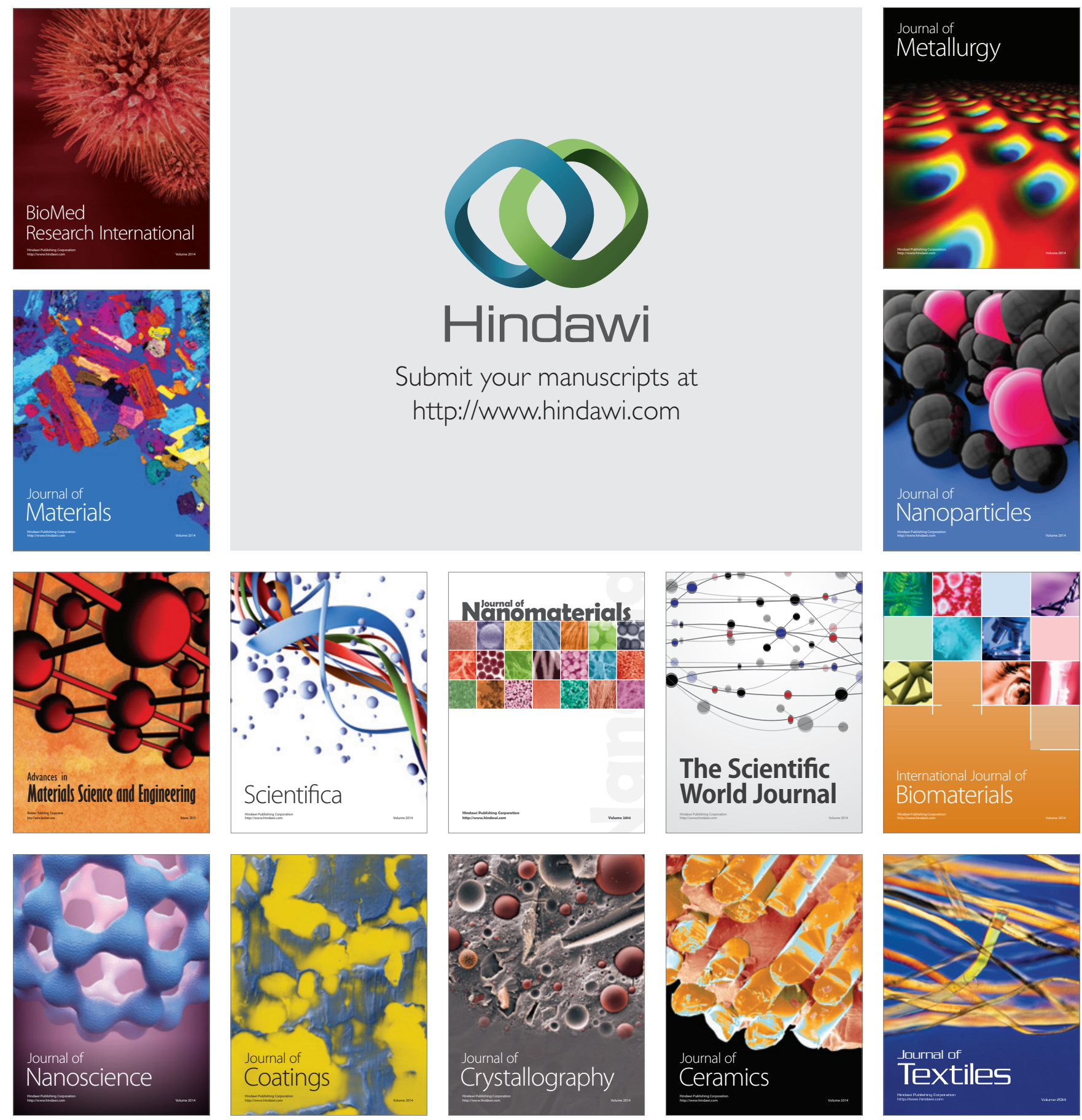